\title{
Социальная справедливость в здравоохранении: опыт и оценки россиян ${ }^{1}$
}

\author{
Ж.В. САВЕЛЬЕВА*, Л.М. МУХАРЯМОВА**, И.Б. КУЗНЕЦОВА***
}

\begin{abstract}
*Жанна Владимировна Савельева - доктор социологических наук, доцент, кафедра истории, философии и социологии, Казанский государственный медицинский университет. Адрес: 420012, Казань, ул. Бутлерова, д. 49. E-mail: gedier@mail.ru

**Лайсан Музиповна Мухарямова - доктор политических наук, профессор, заведующая кафедрой истории, философии и социологии, Казанский государственный медицинский университет. Адрес: 420012, Казань, ул. Бутлерова, д. 49. E-mail: 1.mukharyamova@yandex.ru

***Ирина Борисовна Кузнецова - кандидат социологических наук, доцент, старший научный сотрудник, Школа географии, Земли и наук об окружающей среде, Университет Бирмингема; доцент кафедры истории, философии и социологии, Казанский государственный медицинский университет. E-mail: i.kuznetsova@bham.ac.uk
\end{abstract}

Цитирование: Савельева Ж.В., Мухарямова Л.М., Кузнецова И.Б. (2018) Социальная справедливость в здравоохранении: опыт и оценки россиян // Мир России. Т. 27. № 3. C. 154-179. DOI: 10.17323/1811-038X-2018-27-3-154-179

В статье проанализировань оценки экспертов и мнение населения о справедливости российского здравоохранения. Проблема актуализируется в свете постсоииалистических трансформаций, снижения расходов на здравоохранение, неблагоприятньх показателей здоровья россиян и обрашает к научным дискуссиям в отношении трактовки равенства в сфере здоровья, соотношения прав, возможностей и равенства результатов, ответственности субъекта за здоровье, принципов распределения благ здравоохранения. Эмпирической базой работы являются результаты интервью с экспертами в области организации здравоохранения, пациентами и массового опроса населения двух республик: Татарстан и Марий Эл (2016-2017 г2.).

Результаты исследования выявили следующие проблемы: территориальные программы госгарантий и объемов медицинской помощи приводят к неравенству в доступе к здоровью как на межрегиональном уровне, так и между жителями городских и сельских территорий; своевременная диагностика и лечение малодоступны, прежде всего для по-

1 Работа выполнена при финансовой поддержке РФФИ (№ 16-03-00579а проект «Справедливость и равенство в здравоохранении: мнение экспертов, дискурс масс-медиа и социальные представления пациентов»). 
жильх и малообеспеченных граждан. Вопрос о справедливости здравоохранения в России вызвал затруднения у трети респондентов, мнения остальных разделились примерно поровну; вместе с тем значительная доля населения в последние годы видит улучшение качества здравоохранения своего региона либо оценивает ситуацию как сбалансированную; большинство опрошенных жителей разделяют идеи дистрибутивного понимания справедливости в здоровье, отвергая рыночные принцииы платежей и идеи сопряжения меры ответственности за здоровье и инициативы оплаты медуслуг неработающим населением; лучшими средствами борьбы с несправедливостью в здравоохранении население считает увеличение расходов на здравоохранение, борьбу с коррупцией в высших эшелонах власти и повышение доступности бесплатных медициских услуг. Исследование показало, что положение дел в российском здравоохранении имеет институционально закрепленные механизмы, препятствующие осуществлению справедливых принциипов равных возможностей в отношении здоровья.

Ключевые слова: здоровье, здравоохранение, социальная справедливость, доступность здравоохранения, неравенство в здравоохранении России, реформы здравоохранения

\section{Введение}

Актуальность идеи справедливости для современных обществ не вызывает споров, и дискурс справедливости занимает одну из ключевых позиций во всем спектре политических течений. Исследования показывают, что представления о справедливости имеют конкретно-исторический и конвенциональный характер, теоретические дискуссии определяются не только логикой развития науки, но и теми задачами экономического, политического развития, модернизации и трансформации институтов, которые решаются в данный момент [Данилова 2015, с. 18]. Несмотря на разнообразие подходов к определению этой категории, общим остается факт признания справедливости как самостоятельной ценности, этического принципа, согласующегося с принципами прав человека, которые обладают мощным консолидирующим потенциалом, с одной стороны, и как условия расширения возможностей, способствующего экономическому росту и развитию, с другой.

При характеристике теоретико-методологических предпосылок нашего исследования необходимо подчеркнуть, что дискуссии по проблемам справедливости в отношении здоровья, начавшиеся в последней четверти прошлого века, продолжаются до настоящего времени [Marmot 2017; Braveman 2006]2. Дебаты идут по целому ряду вопросов, важнейшими из которых становятся соотношение равенства возможностей и равенства результатов, проблема автономности и ответственности личности за свое здоровье и определение того, что необходимо измерять - неравенство между отдельными лицами или статусными группами [Arcayaetal 2015; Gakidou, Murray 2000].

2 См. обзор подходов [Мухарямова, Кузнецова 2017]. 
По мнению У. Кимлики, демаркационной линией между представителями различных теорий социальной справедливости выступает идея справедливого распределения и равенства прав [Кимлика 2010]. В отношении здравоохранения это накладывается на различия между подходами к всеобщему благосостоянию, выработанными Дж. Эспин-Андерсоном, - либерализмом с равными правами перед законом, равными экономическими возможностями, но частной медициной, консерватизмом с этатизмом и корпоративизмом и социализмом, который предполагает как универсальные права, так и дифференциальный подход к бенефитам [Van der Veen, Van der Brug 2013]. Страны Латинской Америки Восточной Европы оказываются за рамками данной модели, а «<..> исследование ценностей, поддерживающих институциональную архитектуру государств всеобщего благосостояния в данных регионах еще не было предпринято» [Sachweh 2016, p. 300], в связи с чем сложно использовать ту или иную модель справедливости для анализа. Вместе с тем поскольку корни современной российской системы здравоохранения находятся в социалистической системе, в нашем анализе мы будем большее внимание уделять дихотомии между либеральными и социально-демократическими установками и практиками.

Особое место в дискуссиях по проблеме справедливости занимают перспективы достижения справедливости в отношении здоровья, разрабатываемые на пересечении эпидемиологии, социологии, политической теории, экономики. Огромную роль в распространении идей справедливости в отношении здоровья, в определении концептуальных рамок обсуждения и программы действий внесла специальная комиссия по социальным детерминантам здоровья, созданная Всемирной организацией здравоохранения в 2005 г. Эта комиссия пришла к выводу о том, что распределение денег, власти и ресурсов определяют условия, в которых люди рождаются, растут, живут, работают и стареют. Социальные детерминанты здоровья являются основной причиной несправедливости в отношении здоровья несправедливых и предотвратимых различий в состоянии здоровья, наблюдаемых внутри стран и между ними [Социальные детерминанты 2009]. Как отмечает бывший председатель комиссии М. Мармот (комиссия завершила работу в 2008 г.), неравенство в отношении здоровья вызвано сочетанием социальных программ низкого качества, несправедливыми экономическими механизмами и плохим управлением [Marmot 2017].

Согласно А. Сену, идеи которого оказали значительное влияние на Комиссию, социальная справедливость основывается на возможностях (capabilities), а возможность - это «<..> власть сделать что-то, ответственность, которая исходит от этой способности» [Sen 2009, р. 19]. Таким образом для оценки социальных неравенств, в том числе в сфере здоровья, нужно отталкиваться от неравенства возможностей.

В докладе Всемирного банка «Социальная справедливость и развитие» подчеркивается, что даже при наличии реального равенства возможностей всегда следует ожидать проявления определенных различий в результатах в силу разницы в предпочтениях, способностях, приложенных усилиях, везении [Социальная справедливость 2006, с. 3]. В дискуссию с такой позицией вступает М. Мармот, утверждая, что на практике условия, в которых люди рождаются и растут, настолько сильно различаются, что равенство возможностей - это химера. По мнению М. Мармота, политики любят одобрять равенство возможностей, 
чтобы подтвердить свою приверженность справедливости, но здоровье - это результат цепочки социальных процессов [Marmot 2017, p. 543]. Он подчеркивает наличие разнообразных механизмов, в основе которых находится связь между социально-экономическим положением и здоровьем. Это не только угрозы, создаваемые абсолютной бедностью, но и производный от неблагоприятных социальных сравнений психологический вред (например, стыд, потеря самоуважения) и эрозия социальной сплоченности и солидарности. Социальные детерминанты здоровья и личной ответственности каждого человека приобретают особое звучание в развитых странах, которые показывают, что при достижении определенного дохода его увеличение не влияет на ожидаемую продолжительность жизни [Дитон 2016, с. 51].

Для России значение социальных детерминант здоровья чрезвычайно актуально, поскольку ситуация с состоянием здоровья и продолжительности жизни россиян остается неблагоприятной [Здравоохранение в России 2015; Кислищьна 2015 и др.], и доля россиян, ведущих здоровый образ жизни, весьма невысока [Ермолаева, Носкова 2015]. Изменения в отрасли здравоохранения в постсоветские годы характеризовались масштабным сокращением государственного финансирования, введением рынка платных медицинских услуг, созданием института страховой медицины, децентрализацией государственных финансов и значительным сокращением государственных учреждений, существенными различиями в потенциале разных территорий, ростом неравенства в распределении ресурсов [Шишкин 2008, с. 14]. Зарубежные исследователи считают, что в последние годы наибольшая доля смертей, которых можно было избежать, приходится на страны Африки, Индию и Российскую Федерацию [Garay, Chiriboga 2017]. Малый процент ВВП, выделяемый на здравоохранение, низкая продолжительность жизни, высокий уровень смертей в трудоспособном возрасте от суицидов, алкоголя и табакокурения обусловили попадание России на последнее место в рейтинге эффективности здравоохранения агентства «Блумберг» [Du, Lu 2016]. Начавшаяся в 2014 г. масштабная оптимизация системы здравоохранения, только за первый год приведшая к сокращению 90 тыс. медиков и реорганизации 359 медучреждений, не достигла ожидаемых результатов - «медпомощь не стала ни эффективнее, ни доступнее» [В правительстве услышали замечания 2015]. Среди последствий отмечаются, в том числе, снижение доступности медицинских услуг для жителей села и малых городов [Борта 2016; Миронов 2017 и др.], увеличение нагрузки на медицинских работников [Лонская 2015 и др.]. В последние годы население столкнулось с ростом доли платных услуг: так, в 2016 г. население оплатило более трети расходов на здравоохранение (1,8 трлн из 3,1 трлн руб.) [Улумбекова 2017] $]^{3}$.

Содержание понятия «социальная справедливость» в России за годы постсоветского развития неоднократно трансформировалось, обеспечивая легитимацию изменений в социальной политике. Как указывают исследователи, представления о справедливости в научном и публичном дискурсах с начала 1990-х гг. до настоящего времени прошли путь от критики советской системы, ее уравнительности и доминирования либеральных идей до поиска к концу 2010 гг. коридора

\footnotetext{
3 Восприятие этих изменений с позиций социальной справедливости, по мнению исследователей, остается малоизученным [Аймалетдинов, Моженкова 2015].
} 
возможностей между справедливостью и эффективностью с усилением внимания к проблеме плюрализма, институциональным механизмам достижения справедливости на фоне возрождения радикального эгалитаризма [Темницкий 2017; Вебер 2015; Данилова 2015]. Исследователи отмечают двадцатикратную динамику роста обращений отечественных ученых к проблеме социальной справедливости за этот период, изменение ориентации исследований на решение практических проблем социального регулирования и на углубленный поиск концептуальных подходов [Попова 2016, с. 56].

Применительно к представлениям о справедливости в отношении здоровья следует отметить официальный либерально-консервативный дискурс, создаваемый государственными чиновниками и провластными политиками, и критический дискурс, субъектом которого являются эксперты, представляющие профессиональное медицинское сообщество [Комаров, Ермаков 2015; Улумбекова 2015], исследователи, работающие в поле социальных наук [Власов 2016; Мухарямова 2016; Мухарямова, Кузнецьова 2017; Темницкий 2017].

Можно предположить, что перемены в сфере организации здравоохранения приводят к конфликту с укоренившимися идеалами справедливого здравоохранения и требуют полной реконструкции представлений. А. Сен указывал: «Суть любой теории справедливости можно достаточно полно “ухватить”, обратившись к ее информационной базе: какая информация была использована или не использована в качестве необходимой» [Сен 2004, с. 75]. Поэтому призыв к повышению осведомленности о несправедливости и пропаганде реформ для разрушения укоренившихся структурных барьеров и политики, которые препятствуют справедливости в отношении здоровья, выстраивание доверительных отношений между различными группами, честное изучение предубеждений вполне правомерно применить и к российскому обществу [Chin 2017].

В конфликтных или ущемляющих их интересы ситуациях люди стремятся обосновать справедливость своих притязаний в каждой конкретной ситуации, соотносят свои требования с нормативными требованиями, апеллируют к определенной системе ценностей и аргументов, в рамках которой ситуацию можно интерпретировать выгодным для них образом. Цель исследователя, соответственно, - это выявление и реконструкция таких систем нормативного обоснования справедливости [Болтански, Тевено 2013, с. 37]. В связи с этим, на наш взгляд, изучение представлений населения и экспертного сообщества о справедливости в отношении здоровья является необходимой информационной базой для понимания трансформаций современного здравоохранения.

Какая справедливость востребована населением в сфере здравоохранения: либеральная или дистрибутивная? Отсутствие каких возможностей (capacities) со стороны государства препятствует достижению равного доступа к здравоохранению? Какие варианты распределения ресурсов справедливы с точки зрения экспертов и справедливы ли территориальные различия в регионах? Справедливо или несправедливо равенство в получении одинакового объема бесплатных медицинских сервисов трудоспособных, делающих отчисления в Фонд ОМС и получающих зарплату в «конверте» людей, заботящихся о здоровье, и тех, кто является источником проблем со здоровьем в силу нездорового образа жизни? Статья посвящена исследованию данных вопросов социальной справедливости здравоохранения в региональном контексте на примере Татарстана и Марий Эл. 


\section{Дизайн исследования}

Исследование проводилось в 2016-2017 гг. в двух регионах Российской Федерации: Республике Татарстан (РТ) и Республике Марий Эл (РМЭ). Выбор регионов определен следующими соображениями: оба региона находятся в Приволжском федеральном округе России, имеют сопоставимые природно-климатические и географические условия, но по показателям социально-экономического развития, качества жизни населения существенно различаются. РТ устойчиво занимает лидерские позиции в рейтинге социально-экономического положения российских регионов (пятая позиция в 2016 г.), по качеству жизни (четвертая позиция в 2016 г.), в Национальном рейтинге состояния инвестиционного климата в регионах России возглавляет список наиболее привлекательных регионов-доноров. РМЭ имеет стабильно невысокие рейтинговые оценки социально-экономического положения (69-е место), качества жизни (65-е место) и инвестиционной привлекательности. Сравнение регионов по показателям здоровья населения показывает несколько иную картину: по младенческой смертности РМЭ занимает 24-ю позицию в стране, РТ - 29-ю; по общей заболеваемости всего населения РМЭ 61-ю позицию, РТ - 50-ю, но в интегральном показателе «ожидаемая продолжительность жизни» разрыв снова становится огромным: РТ занимает 8-ю позицию, а РМЭ - лишь на 43-м месте [Рейтинг регионов по качеству жизни 2017, с. 45]. Согласно рейтингу эффективности систем здравоохранения 85 регионов РФ за 2015 г., РТ занимает 24-е место в стране, РМЭ - 28-е. РТ на протяжении многих лет остается регионом с относительно низкой заработной платой медицинских работников: по отношению средней заработной платы врачей к средней зарплате по региону РТ с показателем 131,3 в 2014 г. оказалась в самом конце списка в Приволжском федеральном округе (ПФО), на 2-й позиции с конца списка по стране (хуже ситуация только в Москве - 118,9). РМЭ занимает в этом рейтинге 7-ю позицию в ПФО с показателем 148,1.

Таким образом, РТ обладает не только так называемыми преимуществами «первой природы» (нефть), но и факторами «второй природы» (агломерационный эффект, человеческий капитал, институты) [Зубаревич 2013]. Выбор в качестве поля исследования этих регионов, как нам представляется, способствует более глубокому пониманию влияния социально-экономических факторов на представления населения, экспертов, широкого круга медицинских работников о справедливости здравоохранения.

Мы использовали триангуляцию качественных и количественных методов исследования. На первом этапе были проведены полуструктурированные интервью с представителями различных категорий населения $(\mathrm{N}=33)$, с экспертами в области организации здравоохранения $(\mathrm{N}=25)$, фокус-группы с населением $(\mathrm{N}=9)$ и медицинскими работниками $(\mathrm{T}=4)$. С экспертами в $\mathrm{PT}$ проведено 14 индивидуальных и 3 фокус-групповых интервью, в РМЭ - 10 индивидуальных и одно фокус-групповое интервью (общее количество опрошенных экспертов - 59); с представителями разных социально-демографических групп в РТ проведено 21 индивидуальное интервью и 3 фокус-группы, в РМЭ - 12 индивидуальных интервью и одна фокус-группа (общее количество опрошенных информантов - 133). На втором этапе эмпирическую базу исследования дополнили данные массового опроса $(\mathrm{N}=1021$, 
многоступенчатая выборка с использованием на различных этапах стратифицированного отбора - отбора типового случая и квотного отбора с контролем по полу, возрасту и месту проживания «город/село»).

При изучении доступности медицинских услуг был сделан акцент на исследовании качественных данных. Анализируя интервью, мы использовали интегрированный подход к выработке структуры кодов, который использует как индуктивный метод выделения кодов, так и дедуктивный способ организации рамки для типов кодов. Типами кодов выступили (1) концептуальные коды и субкоды, которые идентифицируют понятия и домены исследования; (2) отношения между кодами; (3) коды с точки зрения информантов, которые идентифицируют позитивное, негативное или нейтральное отношение участников к тому или иному опыту; (4) коды характеристик информантов; (5) коды настроек [Bradley, Curry, Devers 2007]. Финалом анализа выступает теоретическое наполнение, концептуализация полученных данных [Glaser, Strauss 1967].

\section{Региональные и территориальные различия в здравоохранении в контексте справедливости: оценки экспертов}

В интервью со специалистами мнения относительно справедливости в российском здравоохранении актуализировали, прежде всего, проблему региональных и территориальных различий, препятствующих равному доступу к медицинским услугам.

В РФ бесплатная медицинская помощь осуществляется в рамках обязательного медицинского страхования. Федеральный центр устанавливает средние нормативы объема медицинской помощи, средние нормативы финансовых затрат на единицу объема медицинской помощи, средние подушевые нормативы финансирования. Каждый субъект федерации с учетом демографических показателей, плотности расселения жителей принимает свою территориальную программу государственных гарантий в рамках реальной бюджетной обеспеченности. В территориальных программах госгарантий исследуемых регионов на 2017-2019 гг. утвержденные объемы финансирования за счет региональных бюджетов заметно ниже утвержденных Правительством РФ. В РТ финансирование составляет от $82,7 \%$ от утвержденных средних показателей в 2017 г. до 86,9\% в 2018 г. и 86,5\% в 2019 г. В РМЭ объем финансирования территориальной программы не превышает $25,5 \%$ от утвержденных нормативов, что неизбежно приводит к увеличению объема платных услуг.

Практически все опрошенные эксперты считают такую норму закона и такое положение вещей нарушающими принципы равенства и справедливости: «Наличие 85 программ обязательного медицинского страхования - это просто величайшая глупость, которая сразу размывает вопрос с позиции справедливого распределения. Есть базовая программа - единая для исполнения по всей России. Больше не надо и меньше не надо» (эксперт 13, РТ). Эксперты считают, что отсутствие в стране равного финансового обеспечения медицинского обслуживания населения делает декларативными принципы равенства граждан. «Равенства в обеспечении права на здоровье в России нет, - продолжает эксперт, - и этому, по крайней мере, 
две причины. Первая заключается в том, что исторически сложилась неравная инфраструктура, когда в одних регионах есть крупные изентры, а в других нет ничего серьезного. Вторая причина связана с разной бюджетной обеспеченностью региона и политическими устремлениями местных элит. Кто-то развивает здравоохранение, а для кого-то важнее другие проектыл (эксперт 13, РТ).

Специалисты в области здравоохранения указывают, что модернизация российского здравоохранения направлена на централизацию ресурсов и кадров. «Российское здравоохранение движется именно киентрализации всего, в одном какомнибудь городе, <..> например, в столице республики будет огромный изентр, а на периферии, если повезет, то будут маленькие ЦРБ, ФАПьи, но хорошую медицинскую помощь надо будет ждать очень долго», - констатирует молодой доктор из Республики Марий Эл (эксперт 9, РМЭ). Такую стратегию экс-министр здравоохранения РМЭ В.В. Шишкин объясняет изменением технологий: «Увеличение объемов медицинской помошчи не может происходить как в 60-е и 70-е годь, тогда это шло путем открытия больниц, как можно ближе к месту проживания населения. Сегодня технологии оказания медицинской помощи меняются, требуют высокозатратных методов. < .. > Такой уровень медицинской помощи мы можем оказать только в цуентрах, и мы должны предоставить жителю сельской местности такой же уровень помощзи» (эксперт 1, РМЭ). В результате неравномерного распределения средств между регионами и территориями достижение единых стандартов оказания медицинских услуг оказывается невозможным: «Элементарная проблема сочиально справедливого распределения этих благ - это выполнение стандарта. <...> Это невозможно сделать в России, потому что у нас разные уровни учреждений. Если ты оказался в маломощном ЦРБ, тебе сделали одно, если вдруг ты оказался в Москве в федеральном учреждении, тебе сделают совершенно другое. <...> И поэтому единый федеральный медицинский стандарт у нас не действует, то есть не могут быть реализованы по факту, хотя об этом никто не говорит» (эксперт 13, РТ).

Проблемы выстраивания трехуровневой системы медицинской помощи присутствуют во всех без исключения регионах России, на что, например, указывает директор Фонда независимого мониторинга медицинских услуг и охраны здоровья человека «Здоровье» Э.Л. Гаврилов: «Не оценивается потребность на местах, не прорабатывается маршрутизация. В результате реформирования уменьшается доступность первичного амбулаторного звена, растет нагрузка на “скорую помощь”, люди попадают в больницы в запущенном состоянии, растет внутрибольничная летальность» [Гаврилов 2015].

Специалисты в области организации здравоохранения обращают внимание на специфику решения проблем в разных регионах. Татарстан, например, идет по пути создания трех агломераций, которые должны обеспечить доступность высокотехнологичной и специализированной помощи для всех жителей. Как считает эксперт, «<..> максимально возможное в этой ситуации достигнуто. Это создание трех высокотехнологичных зон, на которых на сегодняшний день правительство построило три агломерации: Альметьевскую, Челнинскую и Казанскую. <..> Такое разделение ило от медицины, за основу была взята 90-минутная доступность - это время, необходимое для доставки больного с инфарктом миокарда» (эксперт 2, РТ). Такая модель развития, на первый взгляд, кажется оптимальной, однако эксперты предупреждают о ловушках централизации. Первая 
проблема связана с тем, что часть населения, особенно пожилые люди, до этих центров просто не доберется; эксперты называют причиной «ограниченность горюче-смазочных материалов, неукомплектованность медучреждений (санитарным транспортом), а также ментальность населения, которые уюе разуверились и перестают вызывать медпомощзь» (фокус-группа с экспертами 2, РТ). Вторая ловушка - депрофессионализация врачей в условиях ограниченных оперативных вмешательств, родов и т.д., этот процесс некоторые называют «фельдшеризацией врачей», и она влечет за собой снижение качества медицинской помощи. «К сожалению, в маломощныхх районах смертность в экстренных хирургических больных возросла в три раза за последние 15 лет. Вот вам и изменения, связанные с моделью здравоохранения», - отмечает специалист по организации здравоохранения на основе проведенного медико-статистического исследования (эксперт 13, РТ). Третья проблема - это еще большее снижение привлекательности сельского здравоохранения для молодых кадров. В Татарстане действует программа «Миллион на село», предоставляющая выпускникам медицинских вузов жилье в сельской местности. По словам министра здравоохранения Татарстана А.Ю. Вафина, с 2012 г. в села направлено более 300 специалистов (эксперт 2, РТ). Вместе с тем даже данная программа не решает проблему дефицита медицинских кадров в сельской местности.

Отдельной проблемой является то, что централизация здравоохранения в крупных центрах не сопровождается информированием населения о возможностях и правилах получения специализированной и высокотехнологичной медицинской помощи, формируя представления о снижении доступности здравоохранения для жителей малых городов и села [Савельева, Кузнецова, Мухарямова 2017]. «Мы не всегда можем донести (до населения - авторы) о тех проиессах, которые имеют место на сегодняиний день в обществе, в государстве, о происходящей реорганизациии» (эксперт 1, РМЭ).

Эксперты считают, что ситуация, когда каждый субъект федерации принимает свою программу госгарантий в зависимости от наполнения бюджета, является неправильной не только по отношению к пациентам, но и по отношению к медицинским работникам: «Каждая территория принимает свои программы по мере того, какие у нее есть деньги. Москва назначает врачам в три раза выле зарплату при том, что люди делают одну и ту же работу. Вот эти вещзи в системе справедливого государства невозможныл (эксперт 13, РТ). В результате происходит миграция медицинских работников в регионы, где более высокий уровень финансирования здравоохранения, что приводит к нехватке кадров в регионах, испытывающих дефицит финансов. Главный врач одной из ЦРБ РМЭ отмечает, что близость Татарстана для него проблема: «У нас большой отток идет в лечебные учреждения Зеленодольска, Казани, потому что республики находятся на разном уровне по финансовым доходам, сочииальным гарантиям. Если Татарстан готов предоставлять сегодня квартиры своим специиалстам, то в РМЭ, к сожалению, этого нет. У нас в последнее время человек пять ушли туда на должность и жилье» (эксперт 2, РМЭ). В результате такой политики, по словам министра здравоохранения РТ А.Ю. Вафина, в Татарстане «<..> прием врачей из других регионов в последние годы составил 269 человек» (эксперт 2, РТ). Это увеличивает напряженность в регионах с дефицитом финансирования: «Нужно уменьшить нагрузку на врача, увеличить зарплату, дать сочиальные гарантии, 
чтобы народ не уезжал. Из Марий Эл очень много квалифицированного народа уезжает в Татарстан. И у нас из-за этого нагрузка на врача огромная и физически работаем на износ. Качественно принять все население один специалист не может» (эксперт 4, РМЭ).

Специалисты и в Татарстане, и в Марий Эл обращают внимание еще на одну проблему - разделение здравоохранения по границам субъектов федерации, когда пациент должен обращаться за медицинской помощью в областную больницу своего субъекта федерации, иногда за сотни километров, в то время как значительно ближе к нему расположены крупные центры других регионов: «Расстояние от Агрыза до Ижевска - 40 километров, но в случае инсульта пациента повезут в Набережные Челны, расстояние в четыре раза больше» (эксперт 13, РТ). Юридически гражданин может обратиться в любую медицинскую организацию, но фактически реализовать это право непросто. «Скорая помощь» не доставит пациента в другой регион, и врачам не очень хочется принимать пациентов из других областей из-за дополнительных проблем по получению страховых сумм. По мнению экспертов, страна должна идти по пути создания однотипных медицинских организаций, экстерриториальных по подчиненности, не привязанных к конкретным субъектам федерации или муниципальным образованиям, чтобы в них медицинская деятельность была организована по принципу «7 дней в неделю и одинаковая помощь днем и ночью».

Принципы страховой медицины, предполагающие наличие у пациента права выбора медицинской организации и врача, в регионах практически не работают. Страховая медицина эффективна только при наличии достаточного количества самостоятельных организаций, оказывающих услуги здравоохранения, их транспортной доступности, при высоком уровне потребительской культуры населения. Эксперты отмечают, что «<..> функции, которые в российском здравоохранении осуществляют частные страховые организации, выполняя роль посредников между Фондом обязательного медицинского страхования и медицинской организацией, неясньл. При этом они отрезают себе ощутимый кусок из и так небольшого бюджета здравоохранения» (эксперт 1, РТ).

Равная доступность медицинской помощи по муниципальным образованиям регионов также оценивается неоднозначно. Вся ответственность за организацию здравоохранения в настоящее время возложена на государство, а муниципальным образованиям оставлена функция, подразумевающая «создание условий для оказания медицинской помощи населению». Большинство опрошенных экспертов обращают внимание на размытость понятия «создание условий». В одних случаях это «<..> довести до гранищьы ЦРБ теплотрассу, электроснабжение, асфальт; некоторые говорят: “Они должны квартиры давать и так далее”, хотя сегодня это полномочия субъекта РФ» (эксперт 13, РТ). Исследования, проведенные А.А. Гильмановым по сельским муниципальным районам Татарстана с численностью населения менее 25 тыс. чел., показывают, что по итогам 2014 г. фактически подушевой размер финансирования на жителя в худших и лучших районах различается на 52\%. В период 2000-2014 гг. в этих районах первичная заболеваемость возросла на 38\%, а распространенность болезней - в два раза. Рост болезней органов кровообращения составил $82 \%$, онкологических болезней $-57 \%$, травм, отравлений и некоторых других последствий воздействия внешних причин - 25,6\% [Гильманов 2016]. 
Медицинские работники промышленных городов подчеркивают, что в их районах ситуация осложнилась в связи с тем, что в советское время все крупные предприятия имели свои медсанчасти, сформировали высокие ожидания обеспеченности своей заводской медицины. Так, руководитель отдела здравоохранения промышленного города в Татарстане поясняет: «Пенсионеры все ходят и себя в грудь бьют, что они строили этот город, что они тут всем этим (промыпленнылми выбросами) дыимали, а мы им не можем бесплатно предоставить медицинскую помощь» (эксперт 8, РТ).

Вполне очевидно, что реальное положение дел в российском здравоохранении имеет институционально закрепленные механизмы, препятствующие осуществлению справедливых принципов равных возможностей в отношении здоровья.

\section{Справедливость здравоохранения: результаты анкетного опроса и интервью жителей регионов}

Экспертные оценки справедливости здравоохранения в контексте региональных и территориальных различий было интересно сопоставить с представлениями о справедливости населения данных регионов. В анкетном опросе был задан вопрос об общей оценке жителями республик ситуации в региональном здравоохранении и медицине. Респонденты, проживающие в Республике Татарстан, более положительно оценивали ситуацию за последние 10 лет в регионе по сравнению с опрашиваемыми в Республике Марий Эл (взаимосвязь между переменными присутствует $-\chi^{2}=12,222$ при $\left.\mathrm{p}<0,016\right)$.

При ответе на вопрос «В целом как Вы оцениваете состояние здравоохранения и медицины за последние десять лет в регионе, где Вы живете?» многочисленную группу (39,8\%) составили респонденты, выбравшие позицию «в чем-то лучше, в чем-то хуже» - 41,7\% в РТ, 37,9\% в РМЭ. Об ухудшении состояния медицины и здравоохранения в РТ заявили $13,6 \%$ респондентов (4,6\% указали, что оно «немного ухудшилось», 9\% выбрали вариант «стало хуже»). Ухудшение ситуации с медициной и здравоохранением в РМЭ отметили 21,7\% опрошенных (по мнению 8,9\% респондентов, она «немного ухудшилась», по мнению 12,8\% - «стала хуже»). На улучшение ситуации в РТ указали 44,8\% участников анкетирования, проживающих в Татарстане (27,6\% заметили небольшие улучшения, 17,2\% - значительные), и 40,5\% опрошенных, проживающих в РМЭ $(25,6 \%)$ отметили небольшие улучшения, 14,9\% - значительные) (рисунок 1).

При сопоставлении распределения ответов об оценке ситуации в системе здравоохранения за 10 лет и уровня доходов респондентов обнаруживается взаимосвязь между переменными $\left(\chi^{2}=25,191\right.$ при $\left.\mathrm{p}<0,001\right)$. Опрошенные по уровню потребления, соотнесенные нами с «бедными», чаще остальных замечают ухудшение ситуации, в то время как группа «состоятельные» оценивают ситуацию в здравоохранении положительно, выбирая варианты ответа «немного улучшилось» или «стало лучше»: так, значительное или частичное улучшение ситуации в двух регионах заметили 35\% бедных, 40\% лиц со средним доходом, 52\% «состоятельных». О значительном или частичном ухудшением ситуации сообщили $22,2 \%$ «бедных», 16,5\% представителей группы со средним доходом и лишь 9,6\% «состоятельных». 
Такое распределение, на наш взгляд, объясняется тем, что имеется дефицит бесплатных медицинских сервисов, активно расширяется рынок платных услуг, и развитие платного сегмента повышает доступность медицинских услуг для обеспеченной части населения. При этом тип населенного пункта (столица субъекта, город, село) не имеет статистически значимой взаимосвязи с оценками ситуации медицины и здравоохранения в регионах.

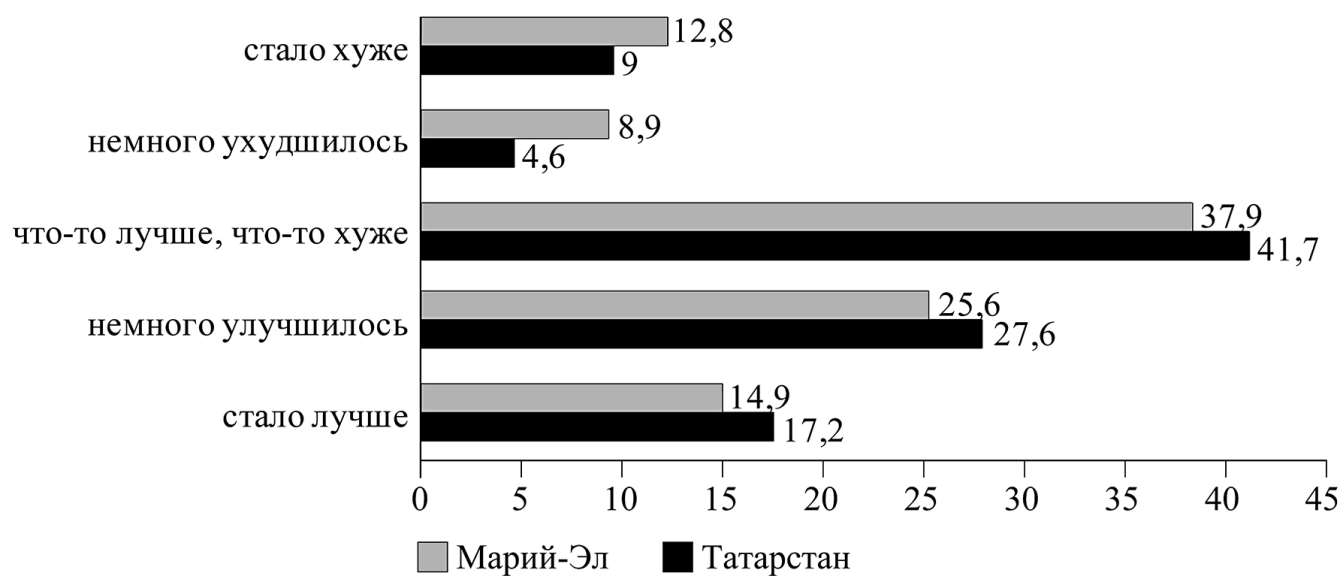

Рисунок 1. «В целом как Вы оцениваете состояние здравоохранения и медицины за последние десять лет в регионе, где Вы живете?», \%

Ключевым в рамках проекта являлся вопрос об общей оценке справедливости системы здравоохранения России населением регионов, который был сформулирован следующим образом: «В современной России система здравоохранения в целом, на Ваш взгляд, является справедливой, скорее справедливой, скорее несправедливой, несправедливой?». Помимо четырех вариантов ответа респондентам предоставлялся вариант «затрудняюсь ответить». Почти каждый третий опрошенный затруднился ответить на данный вопрос $(29,5 \%$ от общей совокупности респондентов). Из тех, кто высказали свое мнение, 9,8\% заявили, что система здравоохранения России является справедливой, 37,3\% - скорее справедливой, 36,5\% - скорее несправедливой, 16,4\% оценили ее как несправедливую.

На фоне более позитивных оценок жителей РТ ситуации в системе здравоохранения республики по сравнению с населением Марий Эл парадоксальным выглядит мнение жителей республик о справедливости российской системы здравоохранения в целом (на присутствие взаимосвязи переменных указывает $\chi^{2}=15,934$ при $\left.\mathrm{p}<0,001\right)$ : доля респондентов РТ, оценивающих здравоохранение как несправедливое, выше, чем доля таких оценок среди опрошенных, проживающих в РМЭ - 57 и 46\% соответственно, в то время как доля, признающих систему справедливой, в РТ составляет 43\%, в РМЭ - почти 54\%. Возможное объяснение кроется в уровне притязаний жителей республик, связанных с уровнем жизни, при этом пол респондента, его доход и тип населенного пункта (столица субъекта, 
город, село) не имеют статистически значимой взаимосвязи с оценками справедливости российского здравоохранения в целом.

В интервью с населением обоих регионов критика здравоохранения, прежде всего касалась нехватки «узких» специалистов, вынужденной необходимости получения платных услуг и долгого ожидания приема на бесплатной основе. Нехватка специалистов отмечается и в области охраны здоровья детства: «У нас нет “узких” детских специиалистов, приходится обрашцаться к специалистам для взросльх или ждать приезда специилистов на медосмотры раз в месяи по субботам. Туда стекается весь район с детьми, собирается большая очередь и, естественно, врачи не могут всех принять» (женщина, 30 лет, проживает в селе в Татарстане).

Относительно длительных очередей весьма типична следующая история женщины из Казани, диагностика порока сердца которой заняла более полугода: «К “узким” специалистам попасть, конечно, проблема, хотя мой участковый врач мне назначил. <...> У него было подозрение на порок сердия, это было в прошлом году в октябре месяцее. <...> Меня пригласили (на УЗИ - авторы) в первылй раз в феврале, и это длилось с октября. Но так как я работала в тот день и не было возможности перенести на другой день, и вот я буквально попала только в мае. То есть это сколько месячев? < .. > Ия еще до сих пор у кардиолога не была, потому что надо попасть к терапевту, и только потом терапевт пошлет меня к кардиологу» (женщина, РТ).

Нередко перед пациентами даже не стоит выбор платных или бесплатных услуг, поскольку система ориентирует их на частную медицину: «Справедливо так-то, с одной стороны, но с другой, смотря, какая болезнь у тебя. Да, доступность все-таки меньше. На платно больше переводят. Бывает так: однажды я стоял возле регистратуры и говорят: “Врача нет”. А фактически врач есть, но за деньги» (мужчина, 48 лет, РТ). «Ну, не придумали ж бесплатно. В очереди стояли бы, но пусть бесплатно делают. Сколько же так время протянется? Хочешь, говорят, узнать про болезнь, иди в платную. А если начнешь в платную ходить, то вся пенсия уйдет. И денег не хватит, и дорого все это. И вот, например, чтобы обследовать два органа, надо заплатить пять тысяч» (женщина, 66 лет, РТ).

Опрошенные жители Марий Эл часто отмечали в интервью, что им приходится сталкиваться с отсутствием необходимых специалистов из-за оттока медицинских кадров: «Сейчас система здравоохранения делает большие и уверенные шаги вперед, и это очень хорошо, но, к сожалению, такая тенденция наблюдается в крупных городах, для маленьких сельских больниц почти ничего не делается. У нас в больнице дефицит специиалистов, и никто не хочет идти работать, потому что маленькие зарплаты, условия у нас здесь не очень, поэтому и бегут все отсюда» (женщина, 23 лет, проживает в селе в Марий Эл). Также, по сравнению с опрошенными из Татарстана, в Марий Эл чаще указывалось на то, что пациентам приходится обращаться на платной основе в соседние регионы: «Нам в маленьких поселках не хватает специалистов, оборудования для диагностики различных заболеваний. Приходится обращцаться в соседние республики, приходиться платить, очень сложно получить квоту на операцию, направление на обследование приходится тоже выпрашивать» (женщина, 51 год, РМЭ). 


\section{Какая справедливость нам нужна: равенство прав или равенство распределения ресурсов?}

Одной из задач исследования стало выявление доминирующих вариантов представлений о справедливости здравоохранения в контексте либеральной и социал-демократической моделей справедливости. В рамках анкетного опроса на определение распространенности понимания справедливости как равенства была направлена серия высказываний, по отношению к которым респондентам предлагалось выразить степень согласия/несогласия. Первое утверждение было следующее: «Гарантированную государством медпомощь все пациенты должны получать в одинаковом объеме». 80,7\% опрошенных выразили полное согласие с высказыванием, 11,4\% выбрали вариант «скорее согласен», примерно 4\% предпочли занять промежуточную позицию («и согласен, и не согласен»), приблизительно по 2\% высказали частичное или полное несогласие с утверждением. Статистически значимых различий в распределении жителей РТ и РМЭ зафиксировано не было.

Следующее высказывание звучало таким образом: «Если гражданин получает зарплату в “конверте”, неофициально, его доступ к бесплатным медицинским услугам должен быть ограничен». Оно было сформулировано в связи с заявленными в 2016 г. и ранее инициативами Правительства РФ о введении так называемого налога на тунеядство, риторики о справедливости ограниченного объема медицинских услуг и платности полисов ОМС для неофициально работающих граждан. Данные инициативы не были приняты Правительством, однако повлияли на характер дискурса относительно вектора развития здравоохранения в России. Несправедливость оплаты медицинских услуг работающими за трудоспособных безработных пациентов очевидна с позиции либерального подхода и неочевидна с позиции равенства распределяемых благ. Согласие с утверждением в концептуальных рамках предпринятого исследования означало бы установку на неолиберальные императивы в политике здравоохранения. В проведенном опросе данное утверждение получило высокий процент неодобрения: категоричное несогласие выразили 45,7\% опрошенных, несогласие - 14,8\%, 15,2\% выбрали промежуточную позицию «и согласен, и не согласен». Примерно по 12\% респондентов выразили абсолютное или относительное согласие с данным утверждением (рисунок 2). Причем респонденты из Республики Татарстан отвергали утверждение более категорично, чем жители Республики Марий Эл $\left(\chi^{2}=11,508\right.$ при р $\left.<0,02\right)$. При работе фокус-групп участники говорили о том, что «не всегда человек виноват», «по-всякому может случиться», «такая система».

Распределение ответов на вопрос об отношении к идее дополнительного сбора на полис ОМС с тех трудоспособных граждан, которые работают без официального трудоустройства и не делают отчисления в Фонд ОМС, не имело статистически значимых различий. 26\% респондентов поддержали идею соплатежей, 41,4\% выразили несогласие с идеей, каждый третий затруднился ответить.

Более категоричное несогласие населения Татарстана было зафиксировано и в связи со следующим утверждением в анкете, которое также соотносится с либеральной моделью справедливости здравоохранения: «Объем доступа к здравоохранению должен зависеть от уровня заработной платы и объема налоговых отчис- 
лений - чем больше гражданин перечисляет налогов, тем больше получает услуг» (взаимосвязь между переменными присутствует $-\chi^{2}=12,39$ при $\left.\mathrm{p}<0,015\right)$. Абсолютное несогласие выразили 54,8\% всех опрошенных, «скорее не согласны» 15,8\%. Абсолютное и относительное несогласие выразили 74,1\% татарстанцев и 64,9\% жителей Марий Эл. Среди всех респондентов промежуточную позицию заняли $12,3 \%$, относительное согласие - 8,1\% и абсолютное согласие (9\%) выразили в совокупности $17,1 \%$.

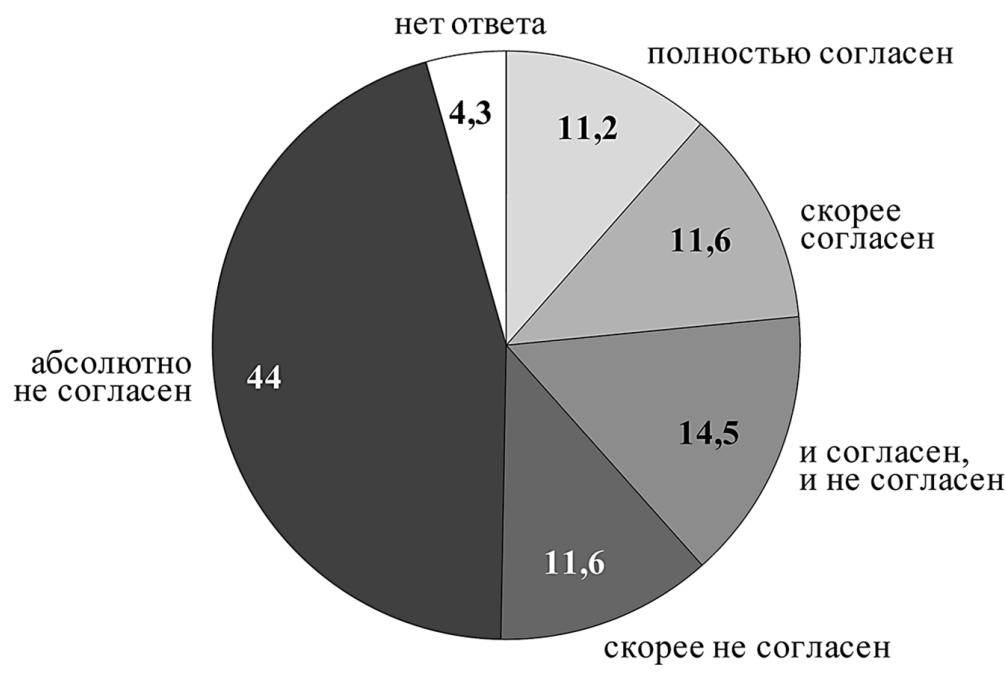

Рисунок 2. «Оцените следующее утверждение:

если гражданин получает зарплату в “конверте", неофициально, то его доступ к бесплатным медицинским услугам должен быть ограничен», \%

Респондентам для выражения степени согласия/несогласия было представлено еще одно утверждение, соотносящееся с правыми идеями справедливости: «Бесплатные услуги необходимо оставить только детям, пенсионерам, инвалидам и бедным, а работающие люди могут оплачивать медуслуги». Абсолютное большинство опрошенных категорично отвергли высказывание $(61,5 \%)$, скорее не согласных с ним - 15,1\%, 9,6\% заняли промежуточную позицию, «скорее согласны» и «полностью согласны» с утверждением - по 6,9\% опрошенных.

Утверждение с указанием на необходимость оплаты услуг средним классом и богатыми людьми получило схожее распределение: абсолютно не согласны $54,1 \%$, скорее не согласны - 17\%, «и да, и нет» - 11,5\%, скорее согласны - 6,7\%, полностью согласны - 10,8\%. Причем в таком варианте формулировки утверждения, когда речь идет о необходимости частичной оплаты полного пакета медуслуг не всеми работающими, а только более состоятельными, респонденты Марий Эл были настроены менее категорично $\left(\chi^{2}=17,638\right.$ при $\left.\mathrm{p}<0,001\right)$ : так, абсолютное несогласие выразили 58,2\% респондентов РТ и 47,8\% респондентов РМЭ, в то время как доля полностью согласных в РТ - 8,4\%, в РМЭ - 14,7\%. Это может 
не только и не столько говорить о менее выраженных либеральных установках населения РТ по сравнению с РМЭ, сколько об отсутствии идентификации жителей РМЭ собственной социально-экономической диспозиции со средними и высшими слоями населения, соотнесении себя с низшим классом работающих, а значит, готовности к тому, чтобы «другие» оплачивали часть медуслуг как более обеспеченные.

Это подтверждает сопряжение данной переменной с уровнем дохода респондентов. Через косвенные вопросы о возможностях потребления были выделены 6 групп респондентов по уровню дохода, которые затем были перекодированы в три условные группы: «бедные», «средний класс», «состоятельные» (таблица 1). Взаимосвязь между переменными подтвердил статистический критерий $\chi^{2}=26,748$ при $\mathrm{p}<0,001$. В группе «бедных» с данным утверждением согласны $16,7 \%$ респондентов, в группах, ассоциированных со средним и высоким доходом, - 8,2 и 7,4\% соответственно. Также среди группы бедных примерно на 9\% меньше респондентов, выразивших полное несогласие с рассматриваемым утверждением, при этом между переменной уровня дохода и оценкой предыдущего утверждения (о возможной оплате полного пакета медуслуг работающими) статистическая связь отсутствовала.

Таблица 1. Оценка утверждения «Бесплатные услуги необходимо оставить только детям, пенсионерам, инвалидам и бедным. Средний класс и богатые должны оплачивать медицинские услуги»

\begin{tabular}{|l|c|c|c|}
\hline & Бедные & Средний класс & Состоятельные \\
\hline Согласен & $16,7 \%$ & $8,2 \%$ & $7,4 \%$ \\
\hline Скорее согласен & $5,9 \%$ & $7,6 \%$ & $5,9 \%$ \\
\hline И да, и нет & $15,3 \%$ & $9,5 \%$ & $10,3 \%$ \\
\hline Скорее не согласен & $13,5 \%$ & $18,3 \%$ & $19,1 \%$ \\
\hline Не согласен & $48,6 \%$ & $56,4 \%$ & $57,4 \% \%$ \\
\hline Всего & $\mathbf{1 0 0} \%$ & $\mathbf{1 0 0} \%$ & $\mathbf{1 0 0 \%}$ \\
\hline
\end{tabular}

Интервью с экспертами показали большее расхождение во взглядах, которое распределилось примерно поровну: так, например, бывший министр здравоохранения РМЭ первым проявлением неравенства в здравоохранении назвал именно факт получения медуслуг официально неработающими гражданами: «В нашей республике чуть более ста тысяч, по нашим данныл, это лица трудоспособного возраста, не имеющие группы инвалидности, не стоящие на учете в службе занятости, формально нигде не работают. То есть они работают, получая либо 
“серую” зарплату, либо самозаняты, при этом никаких отчислений в государство они не делают, и в Фонд социального страхования работодатели за них отчисления не делают, но они требуют такого же к себе отношения, бесплатной медищинской помощчи, бесплатного образования, бесплатных социиальных гарантий. Вот первое, в чем я вижу неравенство между государством и гражданами» (эксперт 1, РМЭ).

Некоторые опрошенные считают, что среди неработающих граждан немало состоятельных: «Наверное, введение частичной оплаты ОМС для неработаюших справедливо, потому что у нас есть такая категория людей, я опять приведу примеры из своей поликлиники: богатые люди, катающчиеся на джипах, имеющие коттеджи, бегают за бесплатным молоком. Мы иногда очень удивляемся, откуда у них из соцзащчтыь справки. Вот, пожалуйста, неравенство есть. Поэтому очень обидно» (эксперт 9, РТ).

Другая категория медиков считает меру возможного введения платы за медуслуги от официально неработающих граждан несправедливой, но необходимой: «Если с точки зрения Конституциии нашей федерации то, конечно, незаконно: у нас же прописано, что медицина бесплатна, а вот в плане именно сферы медициины, то это будет хорошо. Потому что есть свои проблемы в финансировании: нет дотаций, нет возможности у учреждений» (эксперт 4, РТ). Немало среди опрошенных врачей и тех, кто считает, что медицинские услуги должны быть доступны всем без исключения.

\section{Как обеспечить движение российского здравоохранения по направлению к большей справедливости?}

В одном из вопросов респондентам предлагалось выбрать варианты мер (не более трех вариантов), которые могут обеспечить движение российского здравоохранения по направлению к большей справедливости системы. Вопрос включал 12 ответов, кодифицированных в рамках концептуальной модели исследования, а также предполагал наличие у респондента собственного варианта, отличного от предложенных.

Самым популярным ответом среди опрошенных (51\%) стало утверждение о необходимости увеличения затрат на здравоохранение в бюджете страны, при этом в РМЭ его поддерживали значительно чаще, чем в РТ $\left(\chi^{2}=5,599\right.$ при р $\left.<0,018\right)$.

Вторыми по популярности (41\%) стали варианты ответов, отсылающие к идеям о необходимости предотвращения коррупции в высших эшелонах власти, значительном росте зарплат врачей с одновременным повышением их ответственности, улучшении профессионального обучения врачей и увеличении требований к ним. Региональные различия в оценках населения по поводу коррупции проявились в большей доле респондентов РТ, выбравших данную меру как приоритетную для справедливости $\left(\chi^{2}=4,825\right.$ при $\left.\mathrm{p}<0,028\right)$. Кроме того, доля предпочетших данную меру чаще была представлена более молодыми возрастами (взаимосвязь с переменной возраста присутствует $\left(\chi^{2}=9,229\right.$ при $\left.\left.\mathbf{p}<0,026\right)\right)$. Жители РТ также чаще высказывались в пользу улучшения профессионального обучения врачей (47\% в РТ и 31\% в РМЭ). 
Третья по популярности мера, выбранная участниками опроса, касалась необходимости отмены оказания платных услуг в государственных учреждениях. Данный вариант ответа был выбран 44,4\% респондентов из РТ и $37,5 \%$ опрошенных, проживающих в РМЭ. Отсутствует взаимосвязь данной переменной с полом опрашиваемых, но есть связь с признаком возраста: чем старше группа респондентов, тем больше доля, выразивших согласие $\left(\chi^{2}=8,698\right.$ при $\left.\mathrm{p}<0,034\right)$, что объясняется сохранением у старшего поколения социалистических представлений о модели справедливости. Также зафиксирована взаимосвязь с уровнем дохода: более популярна мера среди бедных, меньше популярности среди среднего слоя, наименьшая доля выбравших вариант - среди состоятельных $\left(\chi^{2}=6,422\right.$ при р $\left.<0,04\right)$, что также соответствует предположению о распространенности антирыночных взглядов в нижнем сегменте социальной структуры.

Средними по частоте выбора стали такие варианты достижения справедливости, как усиление ориентации на профилактику $(22,4 \%)$, запрет для депутатов и госслужащих на получение медицинской помощи в зарубежных странах (19\%), открытие для граждан объективной информации об объемах медицинской помощи, на которую они могут рассчитывать (15\%).

Статистически значимые различия были обнаружены при сопряжении признака проживания РТ/РМЭ и доли выбравших меру профилактики: в республиках данный вариант выбрали 26 и 16\% опрошенных соответственно. Это верно и относительно необходимости объективной информации об объемах медицинской помощи: данную меру как первоочередную рассматривают $17,4 \%$ респондентов РТ и $12 \%$ в РМЭ.

Менее предпочтительными среди выбранных респондентами оказались варианты мер, связанных с ликвидацией всех государственных медицинских организаций и создание частных, которые могли бы организовывать здравоохранение за счет бюджетных средств $(3,6 \%)$; отказ в предоставлении медицинских услуг тем трудоспособным гражданам, которые не работают, не платят налоги и не делают отчисления в Фонд ОМС (7\%); введение частичной платы за поведенческие риски здоровья (экстремальный спорт, курение, алкоголизм и т.д.). Таким образом, либеральные варианты решения проблемы получили наименьшее количество выборов среди жителей регионов.

Интервью с медицинскими работниками показали другие мнения относительно движения к большей справедливости. Понимая состояние финансирования отрасли, медики склонялись к неотвратимости увеличения платных услуг, хотя морально далеко не все были с этим согласны. Указывалось, насколько небольшие медицинские учреждения испытывают неудобства от необходимости введения платных услуг, которые даже не могут покрыть обязательных расходов: «Самый вредный показатель, я считаю, индикативной этой эффективности так называемой работы поликлиники, это когда с меня, с нашего учреждения снимают балль, если я не нараму платные услуги. И если ДРКБ в месяи зарабатывает 6 миллионов, то у меня в год получается, например, 300 тысяч рублей. Это копейки, их не хватает. Зато нам потом говорят: "У Вас есть деньги с платных услуг, используйте их”. Например, мне нужно оплатить технический паспорт БТИ, а мне: "У Вас платные услуги”. А эти платные услуги - кутарки. Мы 150 тысяч брали, а чистыми - это 100 тысяч я должна буду разделить на все другие нужды учреждения. Я даже 
не могу себе купить тест-полоски для лаборатории. "Вам не хватает на манmу, туберкулин - докупите из платных услуг! ”» (эксперт 4, РТ). Необходимость введения платных услуг государственными учреждениями отмечалась и в Марий Эл: «Бюджетные медищинские организаџии на что-то должны жить. Если у них финансирование идет на бюджетной основе, то на все расходы, которые нужно, не хватает. Тем более сейчас это сокращается, поэтому в принципе как-то надо зарабатывать, это все стоит достаточно дорого» (эксперт 2, РМЭ).

\section{Заключение}

Проведенное исследование показывает, что единого мнения по стратегии построения в российском обществе справедливого здравоохранения нет. Представления и оценки экспертов и населения поляризованы, выражают разную степень неудовлетворенности, содержат дифференцированные подходы к определению вектора развития отрасли. Объединяет эти позиции обоснование своих идей путем обращения к советской (бесплатной и общедоступной) модели здравоохранения в качестве нормативной и ценностной системы. Главным маркером справедливости в отношении здоровья является требование ст. 41 Конституции РФ, гарантирующее каждому право на бесплатную охрану здоровья и медицинскую помощь в государственных и муниципальных учреждениях здравоохранения. Такой ориентир для общественного мнения поддерживается дискурсами, создаваемыми государственными органами, чиновниками, парламентариями.

По мнению экспертов, наличие в современном российском обществе институциональных оснований для нарушения принципов равенства и справедливости в отношении здоровья (огромные различия в финансовом обеспечении программ государственных гарантий бесплатной медицинской помощи в субъектах федерации, разные объемы финансирования лекарственного обеспечения больных редкими (орфанными) заболеваниями, других льготных категорий пациентов и др.), не всегда являющиеся только следствием различий в обеспеченности региональных бюджетов, но и результатом выбора приоритетов руководителями регионов, остается за пределами общественного диалога.

Программы госгарантий принимаются исполнительными органами власти и не проходят широкого общественного обсуждения, объемы и порядок оказания бесплатной медицинской помощи для граждан не являются прозрачными. Дефицит финансирования программ государственных гарантий приводит не только к снижению доступности медицинской помощи, но и к дисфункциям системы здравоохранения, поддерживая систему неформальных платежей и вынуждая медицинские организации расширять платные услуги в государственных учреждениях, что неоднозначно оценивается и пациентами, и медицинскими работниками. На необходимость изменения правил оказания платных услуг государственными учреждениями и повышения эффективности информирования граждан об их правах указывает то, что значительная группа респондентов считают отмену платных медицинских услуг в государственных организациях эффективной мерой движения российского здравоохранения к большей справедливости. 
Анкетный опрос жителей республик демонстрирует, что примерно 40\% населения наблюдают улучшение в здравоохранении своего региона. Доля позитивных оценок достоверно выше в группах, обладающих более высоким экономическим статусом. Для бедных групп населения предметом критики являются необходимость вынужденного обращения в платные клиники и в соседние регионы, очереди в бюджетных учреждениях здравоохранения, высокая стоимость лекарств, недостаток информации о своих правах в получении бесплатных услуг.

Часть экспертов разделяет либеральные идеи модернизации системы оказания медицинской помощи: введение принципов ответственности за образ жизни и вредные привычки, софинансирование расходов для лиц трудоспособного возраста, не участвующих в формировании страховых выплат. Большинство опрошенных жителей отвергают рыночные принципы платежей и идеи сопряжения меры ответственности за здоровье и принципа «пользы» трудоспособного гражданина с получаемым объемом медицинских услуг. Респонденты демонстрируют приверженность теории «социальных факторов здоровья», считая, что условия, в которых люди рождаются, растут, получают образование, работают, часто от них не зависят, и в России пока нет условий для учета «индивидуального выбора».

Необходимо подчеркнуть, что гармонизация и легитимация социальной политики в сфере здравоохранения невозможны в условиях отсутствия открытого обсуждения развития здравоохранения в соответствии с текущими и стратегическими планами, противоречивости нормативно-правовых документов, регионального неравенства в доступе к медицинским сервисам, концептуализации социальной справедливости субъектами политической власти и населением во взаимоисключающих моделях либеральной и социалистической направленности.

\section{Литература}

Аймалетдинов Т.А., Моженкова Е.М. (2015) Угрозы принципам социальной справедливости в российской системе здравоохранения // Мониторинг общественного мнения. № 6. С. 67-78.

Болтански Л., Тевено Л. (2013) Критика и обоснование справедливости: Очерки социологии градов. М.: НЛО.

Борта Ю. (2016) Смерть на оптимизации. Кто виноват в уничтожении российской медицины? // Аргументы и факты // http:/www.aif.ru/society/healthcare/ poslat_za_smertyu_kto_dolzhen_spasti_detey_v_rossii

В правительстве услышали замечания Счетной палаты к реформе системы здравоохранения (2015) // Независимая газета // http://www.ng.ru/news/500318.html

Власов В.В. (2016) Почему в России нет реформ здравоохранения // Ясин Е.Г. (ред.) XVI апрельская международная конференция научная конференция по проблемам развития экономики и общества. М.: ВШЭ. С. 378-384.

Вебер А. (2015) Социальная справедливость и развитие // Свободная мысль. № 5. С. 95-108. Гаврилов Э. (2015) Задача Фонда «Здоровье» - выявить «болевые точки» и предложить варианты решения проблем // Общероссийский народный фронт // http://onf.ru/2015/04/07/ gavrilov-zadacha-fonda-zdorove-vyyavit-bolevye-tochki-i-predlozhit-varianty-resheniya/

Где в России врачам жить хорошо: рейтинг регионов РФ по уровню жизни врачей // Рейтинги и новости // http://top-rf.ru/places/166-rejting-regionov-rossii-po-urovnyu-zhizni-vrachej.html

Гильманов А.А. (2016) Причины и факторы, определяющие необходимость изменений в сельском здравоохранении // Бюллетень Национального научно-исследовательского института общественного здоровья имени Н.А. Семашко. Выпуск 3. С. 29-38. 
Данилова Е.Н. (2015) Периоды изменений в социальной политике и представлениях о социальной справедливости в России // Социологическая наука и социальная практика. № 2. C. $18-50$.

Дитон А. (2016) Великий побег. Здоровье, богатство и истоки неравенства. М.: Институт Гайдара. Ермолаева П.О., Носкова Е.П. (2015) Основные тенденции здорового образа жизни россиян // Социологические исследования. № 4. С. 120-129.

Здравоохранение в России (2015). Статистический сборник // Федеральная служба государственной статистики // http://www.gks.ru/bgd/regl/b15_34/Main.htm

Зубаревич Н.В. (2013) Государственное управление в пространстве Российской Федерации: коридор возможностей // Никольский С., Ходорковский М. (ред.) Государство. Общество. Управление: сборник статей. М.: Альпина Паблишерз. С. 339-357.

Кимлика У. (2010) Современная политическая философия. Введение. М.: ВШЭ.

Кислицына О. (2015) Влияние социально-экономических факторов на состояние здоровья: роль абсолютных или относительных лишений // Журнал исследований социальной политики. Т. 13. № 2. С. 289-302.

Комаров Ю.М., Ермаков С.П. (2015) Почему растет смертность в РФ? // Комитет гражданских инициатив // https://komitetgi.ru/analytics/2344/

Лонская A. (2015) Жизнь или инструкция // Эксперт Online // http://expert.ru/russian_reporter/2015/09/zhizn-ili-instruktsiya/

Миронов Н. (2017) Российское здравоохранение превращается в «здравозахоронение» // Московский комсомолец // http://www.mk.ru/politics/2017/04/11/rossiyskoezdravookhranenie-prevrashhaetsya-v-zdravozakhoronenie.html

Мухарямова Л.М. (2016) Дискурсы справедливого здравоохранения в современном российском обществе // V Всероссийский социологический конгресс «Социология и общество: социальное неравенство и социальная справедливость». 19-21 октября 2016 года. Екатеринбург. С. 5212-5222.

Мухарямова Л., Кузнецова И. (2017) Равенство и справедливость в отношении здоровья: к поиску аналитических инструментов оценки // Журнал исследований социальной политики. № 4. С. 651-659.

Попова И.П. (2016) Социальная справедливость в научных дискуссиях 1990-2010-х годов // Мир России. №. 3. С. 56-75.

Рейтинг инвестиционной привлекательности регионов России: тенденции по итогам 2016 года (2016) // Эксперт РА // https://raexpert.ru/ratings/regions/2016

Рейтинг регионов по качеству жизни - 2016 (2017) // РИА рейтинг // http://vid1.rian.ru/ig/ratings/life_2016.pdf

Рейтинг регионов по приверженности населения здоровому образу жизни (2017) // РИА рейтинг // http://www.riarating.ru/infografika/20170921/630073305.html

Савельева Ж.В., Кузнецова И.Б., Мухарямова Л.М. (2017) Информационная доступность медицинских услуг в контексте справедливости здравоохранения // Казанский медицинский журнал. Т. 98. № 4. С. 613-617.

Сен А. (2004) Развитие как свобода. М.: Новое издательство.

Социальные детерминанты здоровья (2009) // Всемирная организация здравоохранения // http://www.who.int/social_determinants/thecommission/finalreport/closethegap_how/ru/ index $2 . h t m l$

Социальная справедливость и развитие. Доклад о мировом развитии 2006. Обзор (2006) // Всемирный банк // http://www.un.org/ru/development/surveys/docs/worlddev2006.pdf

Темницкий А.Л. (2017) Феномен справедливости в оплате труда медицинских работников // Мир России. Т. 26. № 3. С. 64-89.

Улумбекова Г.Э. (2015) Здравоохранение России. Что надо делать. М.: ГЭОТАР-Медиа.

Улумбекова Г.Э. (2017) Три четверти от общих расходов на здравоохранение должно нести государство // Общероссийский народный фронт // https://onf.ru/2017/10/26/ ulumbekova-tri-chetverti-ot-obshchih-rashodov-na-zdravoohranenie-dolzhno-nesti/

Шишкин С.В. (ред.) (2008) Российское здравоохранение: мотивация врачей и общественная доступность. М.: Независимый институт социальной политики. 
Эффективное здравоохранение. Рейтинг ВШОУЗ (2015) // Высшая школа организации и управления здравоохранения // http://www.vshouz.ru/news/77.html?SSr=110133c65215 ffffffff 27c 07e103160f0b09-2dc9

Arcaya M.C., Arcaya A.L., Subramanian S.V. (2015) Inequalities in Health: Definitions, Concepts, and Theories // Global Health Action, vol. 8, no 1, pp. 27106.

Bradley E.H., Curry L.A., Devers K.J. (2007) Qualitative Data Analysis for Health Services Research: Developing Taxonomy, Themes, and Theory // Health Services Research, vol. 42, no 4, 1758-1772.

Braveman P. (2006) Health Disparities and Health Equity: Concepts and Measurement // Annual Review of Public Health, vol. 27, no 1, pp. 167-194.

Chin M.H. (2017) Movement Advocacy, Personal Relationships, and Ending Health Care Disparities // Journal of the National Medical Association, vol. 109, no 1, pp. 33-35.

Du L., Lu W. (2016) U.S. Health-Care System Ranks as One of the Least-Efficient // Bloomberg // https://www.bloombergquint.com/business/2016/09/29/u-s-health-care-system-ranks-as-oneof-the-least-efficient

Gakidou E.E., Murray C.J., Frenk J. (2000) Defining and Measuring Health Inequality: an Approach Based on the Distribution of Health Expectancy // Bulletin of the World Health Organization, vol. 78, no 1, pp. 42-54.

Garay J.E., Chiriboga D.E. (2017) A Paradigm Shift for Socioeconomic Justice and Health: from Focusing on Inequalities to Aiming at Sustainable Equity // Public Health, vol. 149, pp. 149-158.

Glaser B., Strauss A. (1967) The Discovery of Grounded Theory // Sociology. The Journal of the British Sociological Association, no 12, pp. 27-49.

Marmot M. (2017) Social Justice, Epidemiology and Health Inequalities // European Journal of Epidemiology, vol. 32, no 7, pp. 537-546.

Newdick C. (2017) Health Equality, Social Justice and the Poverty of Autonomy // Health Economics, Policy and Law, vol. 12, no 14, pp. 411-433.

Sachweh P. (2016) Social Justice and the Welfare State: Institutions, Outcomes, and Attitudes in Comparative Perspective // Handbook of Social Justice Theory and Research, New York: Springer, pp. 293-314.

Sen A. (2009) The Idea of Justice, Allen Lane and Harvard University Press.

Van der Veen R.J., Van der Brug W. (2013) Esping-Andersen's Measurement Model of Welfare Regimes // British Journal of Political Science, vol. 43, no 2, pp. 323-343.

\title{
Social Justice in Healthcare in the Experiences and Judgments of Russians
}

\author{
Zh. SAVELEVA*, L. MUKHARYAMOVA**, I. KUZNETSOVA***
}

\begin{abstract}
*Zhanna Saveleva - DSc in Sociology, Associated Professor, Department of History, Philosophy and Sociology, Kazan State Medical University. Address: 49, Butlerov St., Kazan, 420012, Russian Federation. E-mail: gedier@mail.ru

**Laissan Mukharyamova - DSC in Politics, Professor, Chief, Department of Department of History, Philosophy and Sociology, Kazan State Medical University. Address: 49, Butlerov St., Kazan, 420012, Russian Federation. E-mail: 1.mukharyamova@yandex.ru

***Irina Kuznetsova - PhD in Sociology, Assistant Professor, Senior Researcher, School of Geography, Earth and Environmental Sciences, University of Birmingham, United Kingdom; Assistant Professor, Department of History, Philosophy and Sociology, Kazan State Medical University. Address: 49, Butlerov St., Kazan, 420012, Russian Federation. E-mail: i.kuznetsova@bham.ac.uk
\end{abstract}


Citation: Saveleva Zh., Mukharyamova L., Kuznetsova I. (2018) Social Justice in Healthcare in the Experiences and Judgments of Russians. Mir Rossii, vol. 27, no 3, pp. 154-179 (in Russian). DOI: 10.17323/1811-038X-2018-27-3-154-179

\section{Abstract}

In this article, we analyze the judgments of experts and the population regarding social justice in the provision of healthcare in Russia. We frame our study in the context of post-socialist transformations, the continuous underfunding of public healthcare and the unfavorable health status of Russians. The study contributes to the debates on the meaning of equality in healthcare provision, the responsibility for personal health and the principles of a just distribution of healthcare. Empirically the study draws on interviews with experts in healthcare provision, patients and a survey of the population in the Republics of Tatarstan and Mari El (2016-2017).

Regardless of the widely recognized (albeit modest) improvements in the quality of healthcare provision in the recent years, we find that the existing system promotes inequality both between and within regions (i.e. between rural and urban areas). Lowincome families and the elderly are largely excluded from modern diagnostics and medical treatment. The system is considered just by only a third of respondents, while the majority have a clear preference towards redistributive healthcare provision over market-based principles. There is a strong demand for increased state spending on public healthcare, anticorruption policies and policies to improve access to state-subsidized medical services.

Key words: health, health care, social justice, accessibility of healthcare, Russia inequality in health care, public health reforms

\section{References}

Ajmaletdinov T.A., Mozhenkova E.M. (2015) Ugrozy printsipam sotsial'noj spravedlivosti v rossijskoj sisteme zdravookhraneniya [The Threats to the Principles of Social Justice in Russian Public Health]. Monitoring obshchestvennogo mneniya, no 6, pp. 67-78.

Arcaya M.C., Arcaya A.L., Subramanian S.V. (2015) Inequalities in Health: Definitions, Concepts, and Theories. Global Health Action, vol. 8, no 1, pp. 27106.

Bradley E.H., Curry L.A., Devers K.J. (2007) Qualitative Data Analysis for Health Services Research: Developing Taxonomy, Themes, and Theory. Health Services Research, vol. 42, no 4, 1758-1772.

Boltanski L., Thévenot L. (2013) Kritika i obosnovanie spravedlivosti: Ocherki sotsiologii gradov [De la justification. Les économies de la grandeur], Moscow: NLO.

Borta Yu. (2016) Smert' na optimizatsii. Kto vinovat v unichtozhenii rossijskoj meditsiny? [Death in Optimization. Who Should We Blame in the Destruction of Russian Healthcare?] Argumenti $i$ fakti. Available at: http://www.aif.ru/society/healthcare/poslat_za_smertyu_ kto_dolzhen_spasti_detey_v_rossii, accessed 31 May 2018.

Braveman P. (2006) Health Disparities and Health Equity: Concepts and Measurement. Annual Review of Public Health, vol. 27, no 1, pp. 167-194. 
Chin M.H. (2017) Movement Advocacy, Personal Relationships, and Ending Health Care Disparities. Journal of the National Medical Association, vol. 109, no 1, pp. 33-35.

Danilova E.N. (2015) Periody izmenenij v sotsial'noj politike i predstavleniyakh o sotsial'noj spravedlivosti v Rossii [Periods of Change in Social Policy and Judgments about Social Justice in Russia]. Sotsiologicheskaya nauka i sotsial'naya praktika, no 2, pp.18-50.

Deaton A. (2016) Velikij pobeg: Zdorov'e, bogatstvo i istoki neravenstva [The Great Escape: Health, Wealth, and the Origins of Inequality], Moscow: Gaydar Institute.

Du L., Lu W. (2016) U.S. Health-Care System Ranks as One of the Least-Efficient. Bloomberg. Available at: https:/www.bloombergquint.com/business/2016/09/29/u-s-health-caresystem-ranks-as-one-of-the-least-efficient, accessed 31 May 2018.

Effektivnoe zdravookhranenie. Rejting VSHOUZ (2015) [Effective Health Care. The Rating of HSHOM]. Vysshaya shkola organizatsii upravleniya zdravookhraneniya. [Higher School of Health Organization and Management - HSHOM]. Available at: http://www.vshouz.ru/news/77.html?SSr=110133c65215ffffffff27c_07e103160f0b09-2dc9, accessed 31 May 2018.

Ermolaeva P.O., Noskova E.P. (2015) Osnovnye tendentsii zdorovogo obraza zhizni [The Main Trends in Healthy Lifestyles]. Sotsiologicheskie issledovaniya, no 4, pp. 120-129.

Gakidou E.E., Murray C.J., Frenk J. (2000) Defining and Measuring Health Inequality: an Approach Based on the Distribution of Health Expectancy. Bulletin of the World Health Organization, vol. 78, no 1, pp. 42-54.

Garay J.E., Chiriboga D.E. (2017) A Paradigm Shift for Socioeconomic Justice and Health: from Focusing on Inequalities to Aiming at Sustainable Equity. Public Health, vol. 149, pp. 149-158.

Gavrilov E. (2015) Zadacha Fonda «Zdorov'e» - vyyavit' «bolevye tochki» I predlozhit' variant resheniya problem [The Goal of the 'Health' Foundation - Revealing 'Sensitive Points' and Suggesting Solutions]. Obshcherossijskij Narodnyj Front [The All-Russian People's Front]. Available at: http://onf.ru/2015/04/07/gavrilov-zadacha-fonda-zdorove-vyyavit-bolevyetochki-i-predlozhit-varianty-resheniya/, accessed 31 May 2018.

Gde v Rossii vracham zhit' khorosho: rejting regionov RF po urovnyu zhizni vrachej [Where in Russia Medical Workers Fare Best: the Regional Ranking of Medical Workers' Level of Living]. Rejtingi i novosti. Available at: http://top-rf.ru/places/166-rejting-regionov-rossiipo-urovnyu-zhizni-vrachej.html, accessed 31 May 2018.

Gil'manov A.A. (2016) Prichiny i faktory, opredelyayushchie neobkhodimost' izmenenij v sel'skom zdravookhranenii [The Causes and Factors Urging Change in Rural Healthcare]. Bulleten'Natsional'nogo nauchno-issledovatel'skogo institute obshchestvennogo zdorov'ya imeni N.A. Semashko, vol. 3, pp. 29-38.

Glaser B., Strauss A. (1967) The Discovery of Grounded Theory. Sociology. The Journal of the British Sociological Association, no 12, pp. 27-49.

Kislitsyna O. (2015) Vliyanie sotsial'no-ekonomicheskikh faktorov na sostojanie zdorov'ya: rol' absolyutnykh i otnositel'nykh lishenij [The Influence of Socio-economic Factors on Health: the Role of Absolute and Relative Deprivation]. The Journal of Social Policy Studies, vol. 13, no 2, pp. 289-302.

Komarov Yu.M., Ermakov S.P. (2015) Pochemu rastet smertnost' v RF? [Why Does Mortality Grow?]. Komitet grazhdanskikh initsiativ [The Committee of Civil Initiatives]. Available at: https://komitetgi.ru/analytics/2344/, accessed 31 May 2018.

Kymlicka W. (2010) Sovremennaya politicheskaya filosofiya. Vvedenie [Contemporary Political Philosophy. An Introduction], Moscow: HSE.

Lonskaya A. (2015) Zhizn' ili instruktsiya [Life or Instruction]. Expert Online. Available at: http://expert.ru/russian_reporter/2015/09/zhizn-ili-instruktsiya/, accessed 31 May 2018.

Marmot M. (2017) Social Justice, Epidemiology and Health Inequalities. European Journal of Epidemiology, vol. 32, no 7, pp. 537-546.

MironovN.(2017)Rossijskoezdravookhranenieprevrashchaetsyav «zdravozahoronenie»[Russian Public Healthcare Transforms into 'Healthdumping']. Moskovskij komsomolets. Available at: http://www.mk.ru/politics/2017/04/11/rossiyskoe-zdravookhranenie-prevrashhaetsya-vzdravozakhoronenie.html, accessed 31 May 2018. 
Mukharyamova L. (2016) Diskursy spravedlivogo zdravookhraneniya v sovremennom rossijskom obshchestve [Social Justice Discourses in Contemporary Russian Society]. V All-Russian Sociological Congress "Sociology and Society: Social Inequality and Social Justice", 19-21 October 2016. Ekaterinburg, pp. 5212-5222.

Mukharyamova L., Kuznetsova I. (2017) Ravenstvo i spravedlivost' v otnoshenii zdorov'ya: k poisku analiticheskikh instrumentov otsenki [Equality and Justice in Health: Searching for Analytical Tools in Evaluating Healthcare]. Zhurnal issledovanij sotsial'noj politiki, no 4, pp. 651-659.

Newdick C. (2017) Health Equality, Social Justice and the Poverty of Autonomy. Health Economics, Policy and Law, vol. 12, no 14, pp. 411-433.

Popova I.P. (2016) Sotsial'naya spravedlivost' v nauchnykh diskussiyakh 1990-2010-h godov [Social Justice in Scientific Debates1990-2010]. Mir Rossii, no 3, pp. 56-75.

Rejting regionov po kachestvu zhizni - 2016 (2017) [The Ranking of Regions by Living Standards]. RIA Rating. Available at: http://vid1.rian.ru/ig/ratings/life_2016.pdf, accessed 31 May 2018.

Rejting regionov po priverzhennosti naseleniya zdorovomu obrazu zhizni (2017) [The Ranking of Regions by the Commitment of Population to Healthy Lifestyles]. RIA Rating. Available at: http://www.riarating.ru/infografika/20170921/630073305.html, accessed 31 May 2018.

Rejting investitsionnoj privlekatel'nosti regionov Rossii (2016) [The Investment Ranking of Russian Regions]. Ekspert RA. Available at: https://raexpert.ru/ratings/regions/2016, accessed 31 May 2018.

Sachweh P. (2016) Social Justice and the Welfare State: Institutions, Outcomes, and Attitudes in Comparative Perspective. Handbook of Social Justice Theory and Research, New York: Springer, pp. 293-314.

Savelyeva Zh., Kuznetsova I., Mukharuamova L. (2017) Informatsionnaya dostupnost' meditsinskikh uslug v kontekste spravedlivosti zdravookhraneniya [The Accessibility of Information about Medical Services in the Context of Social Justice in Healthcare]. Kazan Medical Journal, vol. 98, no 4, pp. 613-617.

Sen A. (2004) Razvitie kak svoboda [Development as Freedom], Moscow: Novoe izdatel'stvo.

Sen A. (2009) The Idea of Justice, Allen Lane and Harvard University Press.

Shishkin S. (ed.) (2008) Rossijskoe zdravookhranenie: motivatsiya vrachej i obshchestvennaya dostupnost' [Russian Healthcare: Medical Workers' Motivation and Accessibility of Care], Moscow: Nezavisimyj institute sotsial'noj politiki.

Sotsial'nye determinant zdorov'ya [Social Determinants of Health]. World Health Organization. Available at: http:/www.who.int/social determinants/thecommission/ finalreport/closethegap_how/ru/index2.html, accessed 31 May 2018.

Sotsial'naya spravedlivost' ${ }^{i}$ razvitie. Doklad o mirovom razvitii (2006) [Social Justice and Development. Global Development Report 2006]. World Bank. Available at: http://www.un.org/ru/development/surveys/docs/worlddev2006.pdf, accessed 31 May 2018.

Temnitsky A. (2017) Fenomen spravedlivosti v oplate truda meditsinskikh rabotnikov [The Phenomenon of Justice in the Labour Remuneration of Medical Workers]. Mir Rossii, vol. 26, no 3, pp. 64-89.

Ulumbekova G. (2015) Zdravookhranenie Rossii. Chto nado delat' [Public Health in Russia. What We Have to Do], Moscow: GJeOTAR-Media.

Ulumbekova G. (2017) Tri chetverti ot obshchikh raskhodov na zdravookhranenie dolzhno nesti gosudarstvo [The Three Quarters of Public Expenses on Health Have to Be Financed From the State]. Obshcherossijskij Narodnyj Front [The All-Russian People's Front]. Available at: https://onf.ru/2017/10/26/ulumbekova-tri-chetverti-ot-obshchih-rashodov-nazdravoohranenie-dolzhno-nesti/, accessed 31 May 2018.

$\mathrm{V}$ pravitel'stve uslyshali zamechaniya Schetnoj palaty k reforme sistemy zdravoohraneniya (2015) [The Government Is Aware of the Audit Chamber's Report on the Reform of the Healthcare System]. Nezavisimaya gazeta. Available at: http://www.ng.ru/news/500318.html, accessed 31 May 2018.

Van der Veen R.J., Van der Brug W. (2013) Esping-Andersen's Measurement Model of Welfare Regimes. British Journal of Political Science, vol. 43, no 2, pp. 323-343. 
Veber A. (2015) Sotsial'naya spravedlivost' i razvitie [Social Justice and Development]. Svobodnaya mysl', no 5, pp. 95-108.

Vlasov V. (2016) Pochemu v Rossii net reform zdravookhraneniya [Why No One Reforms Russian Healthcare]. XVI April International Academic Conference on Economic and Social Development (ed. Yasin E.G.), Moscow: HSE, pp. 378-384.

Zdravookhranenie v Rossii (2015). Statisticheskij sbornik [Russian Healthcare. 2015. Statistical Bulletin]. Federal State Statistics Service. Available at: http://www.gks.ru/bgd/regl/b15_34/Main.htm, accessed 31 May 2018.

Zubarevich N. (2013) Gosudarstvennoe upravlenie v prostranstve Rossijskoj Federatsii: koridor vozmozhnostej [State Regulation in the Space of Russian Federation: the Corridor of Opportunities]. Gosudarstvo. Obshchestvo. Upravlenie [State. Society. Management] (eds. Nikol'skij S., Khodorkovskij M.), Moscow: Al'pina Pablisherz, pp. 339-357. 